\title{
Quartz deposition and its influence on the deformation process of megathrusts in subduction zones
}

\author{
Jun Kameda ${ }^{*}$, Kuniyo Kawabata ${ }^{2}$, Yohei Hamada ${ }^{3}$, Asuka Yamaguchi ${ }^{4}$ and Gaku Kimura ${ }^{3}$
}

\begin{abstract}
We present a quantitative examination of the liberation and subsequent deposition of silica at the subduction zone plate interface in the Mugi mélange, an exhumed accretionary complex in the Shimanto Belt of southwest Japan. Frequency and thickness measurements indicate that mineralized veins hosted in deformed shales make up approximately $0.4 \%$ of the volume of this exposure. In addition, whole-rock geochemical evidence suggests that the net volume of $\mathrm{SiO}_{2}$ liberated from the mélange at temperatures of $<200^{\circ} \mathrm{C}$ was as much as $35 \%$, with up to $40 \%$ of the $\mathrm{SiO}_{2}$ loss related to the smectite-illite (S-I) conversion reaction, and the rest attributable to the pressure solution of detrital quartz and feldspar. Kinetic modeling of the $\mathrm{S}-1$ reaction indicates active liberation of $\mathrm{SiO}_{2}$ at approximately $70^{\circ} \mathrm{C}$ to $200^{\circ} \mathrm{C}$, with peak $\mathrm{SiO}_{2}$ loss at around $100^{\circ} \mathrm{C}$, although these estimates should be slightly shifted toward lower temperature conditions based on X-ray diffraction (XRD) analyses of mixed-layer S-I in the Mugi mélange. The onset of pressure solution was not fully constrained, but has been documented to occur at around $150^{\circ} \mathrm{C}$ in the study area. The deposition in deformed shales of quartz liberated by pressure solution and the S-I reaction is probably linked to seismogenic behavior along the plate interface by (1) progressively enhanced velocity-weakening properties, which are favorable for unstable seismogenic faulting, including very-low-frequency earthquakes and (2) increasing intrinsic frictional strength, which leads to a step-down of the plate boundary décollement into oceanic basalt.
\end{abstract}

Keywords: Subduction zone; Diagenesis; Veining; VLFE

\section{Background}

The deposition of quartz as pore-filling cement and/or veins is a common diagenetic process during burial sedimentation, and can cause dramatic modifications of bulkrock mechanics, including changes in stiffness (Laubach et al. 2004), consolidation behavior (Karig and Morgan 1994), and frictional properties (Lockner and Byerlee 1986). In sandstone reservoirs, quartz cementation starts at approximately $90^{\circ} \mathrm{C}$ (McBride 1989), whereas in shales, evidence of pore-filling cementation is rare, with mineralized veining being a much more common form of quartz deposition (van de Kamp 2008). The $\mathrm{SiO}_{2}$ deposited in sandstone cements is thought to be derived from pressure

\footnotetext{
* Correspondence: kameda@mail.sci.hokudai.ac.jp

'Earth and Planetary System Science, Department of Natural History Sciences, Graduate School of Science, Hokkaido University, N10 W8, Sapporo 060-0810, Japan

Full list of author information is available at the end of the article
}

solution of detrital quartz and feldspar, although some studies emphasize the importance of external $\mathrm{SiO}_{2}$ sources, such as smectite-illite transformation (S-I) reactions in accompanying shales (Hower et al. 1976; van de Kamp 2008).

At subduction margins, incoming sedimentary deposits are buried along the plate boundary thrust. The underthrusting causes these sediments to undergo several diagenetic reactions during burial. These processes might have a first-order influence on the mechanical transition from aseismic shallower deformation to unstable seismic slip in deeper parts of the subduction zone (Moore and Saffer 2001); indeed, quartz cementation and/or veining have been invoked as a cause of the formation of seismogenic plate boundaries (Byrne 1998; Moore and Saffer 2001; Moore et al. 2007). A recent friction experiment by Saito et al. (2013) suggested that lithification of the plate boundary fault due to quartz 
deposition can also cause very-low-frequency earthquakes (VLFE) at shallow subduction zones (less than approximately 10-km depths; e.g., Ito and Obara 2006; Obana and Kodaira 2009; Ando et al. 2012; Sugioka et al. 2012). However, the origin, timing, and volume of this cementation and/or veining have yet to be documented in detail. In on-land accretionary complexes, quartz deposition has been documented in deformed rocks that underwent diagenesis at $100^{\circ} \mathrm{C}$ to $120^{\circ} \mathrm{C}$ (Moore and Allwardt 1980). Byrne (1998) suggested that pressure solution promotes quartz cementation in these types of environments. However, as the majority of plate boundary faults are located in smectite-rich horizons (Underwood 2007), the S-I reaction could also supply significant amounts of silica, although this factor has not been assessed in previous research.

In this study, we examined the behavior of mobilized $\mathrm{SiO}_{2}$ along the subduction zone plate interface by measuring the frequency and volumetric ratio of quartzdominated mineralized veins present within an on-land accretionary complex of the Shimanto Belt (Mugi mélange), Japan. As a possible source for such veining, we focused on the diagenetic S-I reaction in the host-rock shales. For this purpose, bulk and clay fraction mineralogy was investigated by X-ray diffraction (XRD) analyses. We also modeled possible pathways of the S-I reaction by considering the underthrusting sediments in the Nankai margin as an analog setting. Based on these results, we detail the $\mathrm{SiO}_{2}$ behavior and its mechanical consequence on plate boundary faults in subduction zones.

\section{Geological setting}

The Shimanto accretionary complex on Shikoku Island, southwest Japan, is divided into northern and southern sub-belts (Figure 1a; Taira et al. 1980). The Mugi mélange is exposed along the southeastern coast of Shikoku Island and is composed of six repeated thrust sheets (units 1 to 6) bounded by north-dipping thrusts (Shibata et al. 2008; Figure 1b,c). Each unit preserves the original ocean-floor trench stratigraphy, suggesting that the Mugi mélange was an underplated thrust-sheet package that was accreted beneath an ancient accretionary prism during the latest Cretaceous to earliest Paleocene (Onishi and Kimura 1995; Ikesawa et al. 2005; Kitamura et al. 2005; Shibata et al. 2008; Kimura et al. 2011). The Mugi mélange contains disrupted pillows and massive basalts, hemipelagic shale, pelagic red shale, and sandstone lenses enclosed in a sheared argillaceous matrix with scaly fabric (Figure 1b). A systematic deformation fabric is present within the mélange and has been related to underthrusting and underplating (Onishi and Kimura 1995; Ikesawa et al. 2005; Kitamura et al. 2005). Vitrinite reflectance analysis yields paleo-temperatures of $130^{\circ} \mathrm{C}$ to $150^{\circ} \mathrm{C}$ in the lower thrust sheets (Ikesawa et al. 2005) and $>200^{\circ} \mathrm{C}$ in the upper thrust sheets (Kitamura et al. 2005), corresponding to the approximate shallow portion of the seismogenic zone $\left(150^{\circ} \mathrm{C}\right.$ to $350^{\circ} \mathrm{C}$; Hyndman 2007$)$.

Crack-fill veins are ubiquitous in the Mugi mélange (Figure 2a), and occur as two types: extensional cracks in the constricted parts of sandstone boudins (classified as 'vein I' in Matsumura et al. (2003) or 'boudin neck veins' in Yamaguchi et al. (2012)), and cracks along shear fabrics, such as Riedel and Y-surfaces ('vein II' in Matsumura et al. (2003)). These veins are dominated by quartz, but abundant calcite veins are also observed, particularly near the basalt-derived fault zone (Ujiie et al. 2007; Yamaguchi et al. 2012). Heating and cooling experiments of fluid inclusions trapped in quartz veins suggest that these veins formed at temperatures of $125^{\circ} \mathrm{C}$ to $245^{\circ} \mathrm{C}$ and pressures of 92 to $145 \mathrm{MPa}$ (Matsumura et al. 2003). Most of the veins appear to have precipitated during the maximum burial with deformation because vein-filling cracks are consistent with mélange fabric, and other faults related to the exhumation stage do not accompany the veins but are in many cases associated with unconsolidated gouges.

\section{Methods}

\section{Analysis of vein frequency and volumetric fraction}

We examined the occurrence and distribution of mineralized veins hosted in deformed shales (vein II) along a transect that includes the entire section of unit 2 of the Mugi mélange from basal basalts to uppermost terrigenous sandstones (Figure 1c). We used a caliper to measure the thickness of every vein that intersected the transect line. Although our measurement was onedimensional (1-D), the cumulative thickness of veins along the transect is almost equivalent to the volumetric fraction in bulk rock, because the transect runs almost perpendicular to the mélange foliation, and vein II mostly occurs parallel or slightly oblique to the foliation. Basalt-hosted veins were excluded from our analysis because it was not possible to discriminate between veins formed before subduction, associated with near-ridge fluid circulation, from those formed after subduction. When estimating the volume fraction, we also excluded veins in sedimentary horizons around the basal basalt, since $\mathrm{Sr}$ isotope analysis suggested that some of these veins have been influenced by dehydration of the basalt (Yamaguchi et al. 2012).

\section{XRD analyses}

We collected two shale samples (ML-01 and ML-02) from the study area (marked in Figure 1c). For bulk-rock analysis, rock chips were powdered in an agate mortar, and these powders were mounted on sample holders by side-loading to minimize the development of a preferred orientation of clay minerals. Bulk XRD patterns were 

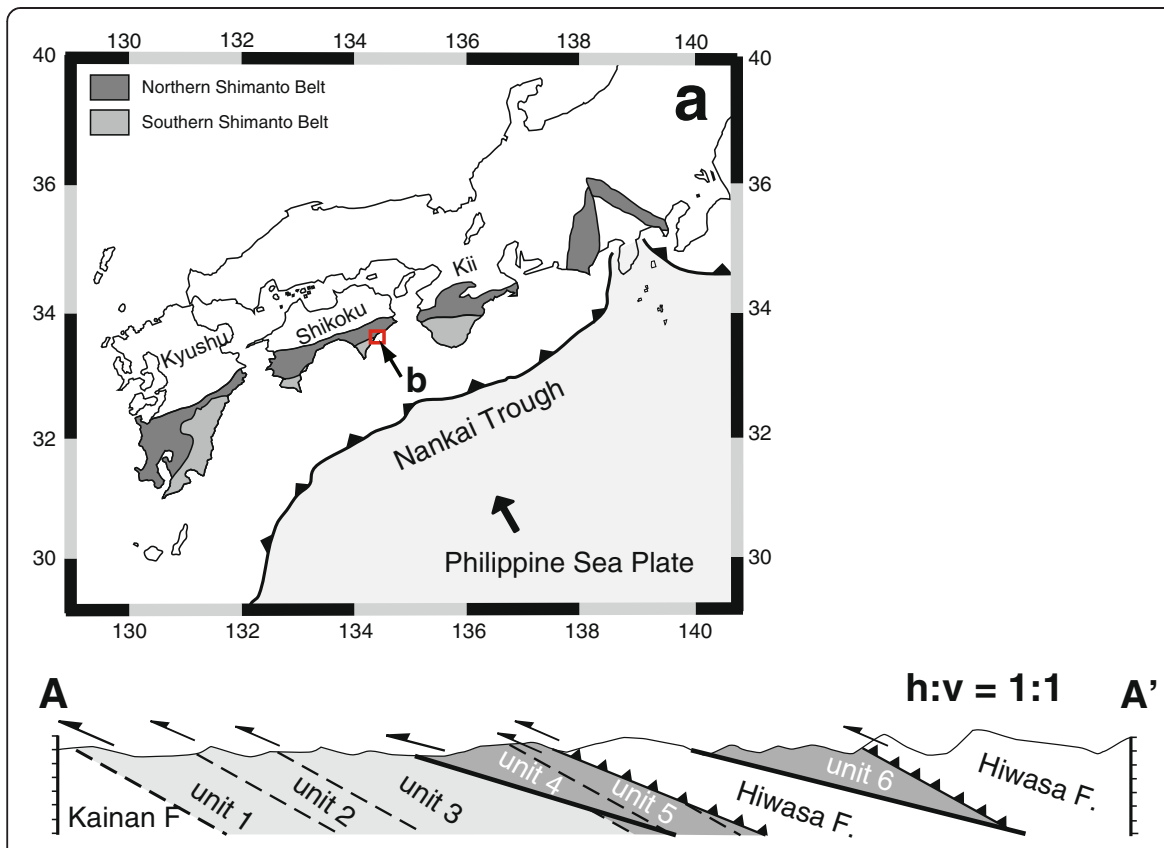

Contour in $50 \mathrm{~m}$ interval
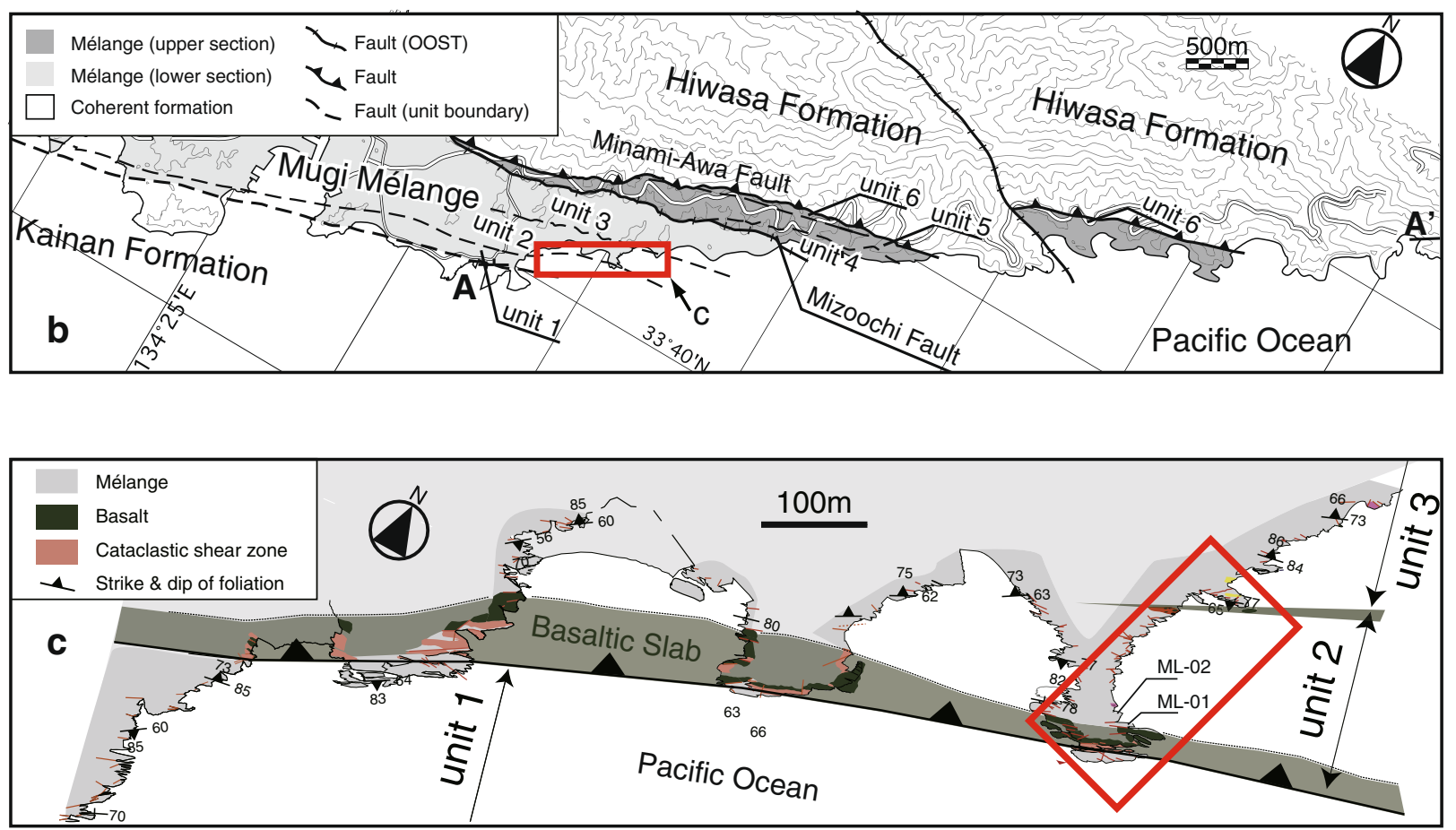

Figure 1 Location of Mugi mélange (a), geological map of study area (b), and sampling locations for XRD (c). Modified after Shibata et al. 2008. OOST = out-of-sequence thrust. Vein occurrences were examined along the coastal traverse marked by a rectangle in (c).

obtained using a MAC Science MX-Labo with monochromatized $\mathrm{CuK \alpha}$ radiation at $40 \mathrm{kV}$ and $30 \mathrm{~mA}$, with $1^{\circ}$ divergence and anti-scattering slits, and a $0.15-\mathrm{mm}$ receiving slit in continuous scan mode at a rate of $1^{\circ} 2 \theta$ per minute. Relative abundances of the constituent minerals (total clays, quartz, plagioclase, and calcite) were estimated by applying a normalization factor given by
Underwood et al. (2003). However, the present analysis is not strictly quantitative because of the difference in experimental apparatus, and thus the data should be considered semi-quantitative.

Other chips were gently crushed and dispersed ultrasonically in distilled water; the clay fraction $(<2 \mu \mathrm{m})$ was then separated by centrifugation and soaked two times in $1 M$ 

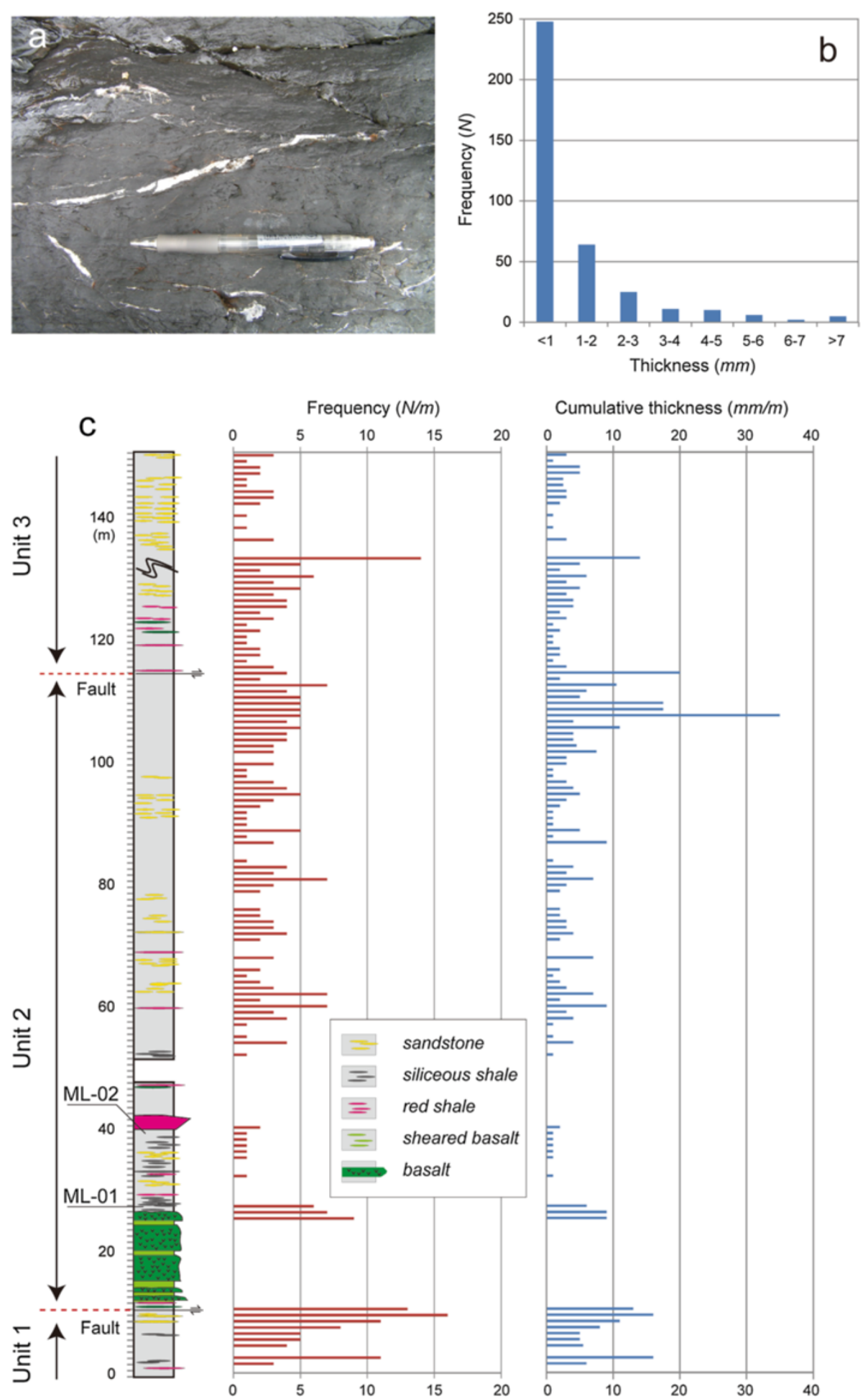

Cumulative thickness $(\mathrm{mm} / \mathrm{m})$

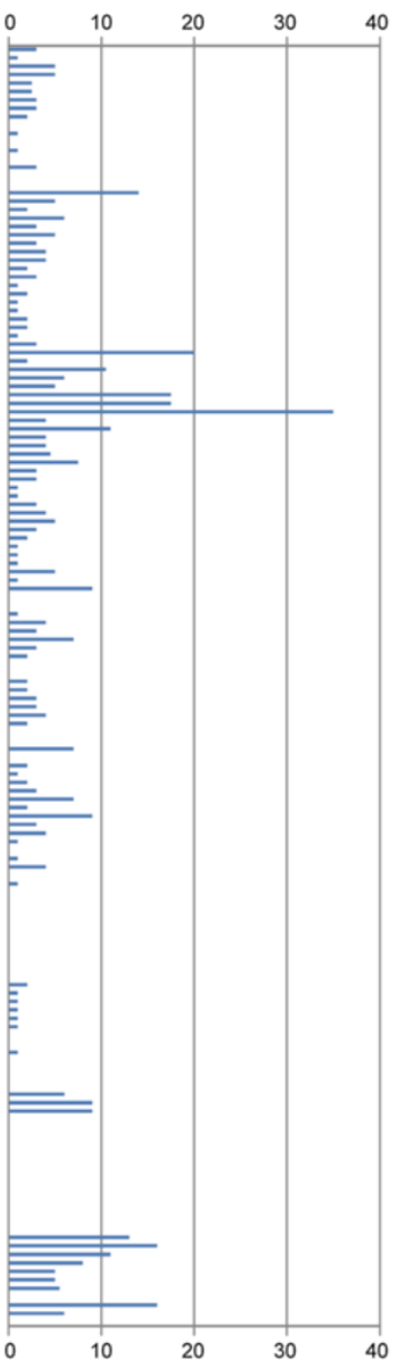

Figure 2 Typical occurrence of mineralized veins (a) and variation in vein thickness (b), frequency, and cumulative thickness (c).

(a) Mineralized veins within the Mugi mélange. (c) Measured at 1-m intervals along the transect line. Sampling locations for XRD are also shown.

$\mathrm{CaCl}_{2}$ solution (for more than $6 \mathrm{~h}$ in each treatment) to prepare Ca-saturated specimens. Suspensions of Ca-saturated specimens were dropped onto glass slides and dried in an oven at $60^{\circ} \mathrm{C}$ (air-dried, $\mathrm{AD}$ ). These mounts were exposed to ethylene-glycol vapor at $60^{\circ} \mathrm{C}$ overnight (EG). XRD patterns for these mounts were recorded using a Rigaku Rint- 
2500 (Advanced Characterization Nanotechnology Platform, The University of Tokyo) with monochromatized $\mathrm{Cu} K \alpha$ radiation at $40 \mathrm{kV}$ and $200 \mathrm{~mA}$, with $0.5^{\circ}$ divergence and anti-scattering slits, and a $0.3-\mathrm{mm}$ receiving slit in continuous scan mode at a rate of $1^{\circ} 2 \theta$ per minute. Relative weight ratios for clay phases were estimated by applying a Biscaye's weighting factor (Biscaye 1965), which assumes a linear correlation between the peak area of the component and its abundance $(1 \times$ for smectite, $4 \times$ for illite, and $2 \times$ for chlorite).

For decomposition of the 10-A peak profile, the samples were rescanned in step scan mode for $4 \mathrm{~s}$ every $0.02^{\circ} 2 \theta$ step, and obtained profiles were processed by DECOMPXR (Lanson 1997). A background was linearly interpolated from 6.5 to $10^{\circ} 2 \theta$ range and subtracted from the experimental pattern. Gaussian curves were composed to fit the original pattern without pattern smoothing. NEWMOD (Reynolds 1985) was used to calculate 1-D XRD patterns for mixed-layered clays.

\section{Modeling of silica release along the plate interface during the S-I conversion reaction}

We used kinetic modeling to quantitatively estimate the amount of $\mathrm{SiO}_{2}$ released during the S-I reaction, based on a general kinetic equation:

$$
-\frac{d S}{d t}=S^{a} \cdot\left(\frac{\mathrm{K}}{\mathrm{Na}}\right)^{b} \cdot A \exp (-U / R T),
$$

where $S$ is the percentage of smectite in S-I crystallites $(\% \mathrm{~S}) ; t$ is time in seconds; $a$ and $b$ are constants that describe the order of reaction; $K$ and $N a$ are the activities of potassium and sodium, respectively; $A$ is the frequency factor; $U$ is the activation energy for the reaction; $T$ is the temperature $(K)$; and $R$ is the gas constant. Pytte and Reynolds (1989) derived an optimal parameter set for this reaction of $a=5, b=1, A=5.2 \times 10^{7} \mathrm{~s}^{-1}$, and $U=33 \mathrm{kcal} /$ mol under the assumption that equilibrium between albite and K-feldspar controls the activity ratio between $\mathrm{K}$ and $\mathrm{Na}$ in the reacting fluid;

$$
\frac{\mathrm{K}}{\mathrm{Na}}=74.2 \exp \left(\frac{-2,490}{T}\right)
$$

The S-I reaction at the Nankai margin, as observed in several drilling holes (Steurer and Underwood 2003), was well reproduced by this kinetic expression (Saffer et al. 2008; Saffer and McKiernan 2009).

We consider the Muroto transect of the Nankai Trough as an analog setting of diagenesis for the Mugi mélange. Temperature-time history for the kinetic modeling is constructed using an underthrusting deposit at a rate of $4 \mathrm{~cm}$ /year in a geothermal structure modeled by Spinelli and Wang (2008). The numerical modeling of Spinelli and Wang (2008) examined the effect of fluid circulation in the upper oceanic crust on the subduction zone thermal condition, and provided two models for the Nankai margin: a cooler one with preferred hydrothermal circulation, and a warmer one with no fluid circulation. The temperature difference of the décollement between the two models at a landward distance of $100 \mathrm{~km}$ from the deformation front is approximately $70^{\circ} \mathrm{C}$. In our kinetic calculation, we also adopted these two models in order to test how the subduction zone thermal model affects the progress of the illitization reaction. Equation 1 was solved numerically by the finite difference method. We used an S-I content value of $40 \mathrm{wt} . \%$ in the incoming deposit, and an initial state of $80 \% \mathrm{~S}$ at the trench of the Muroto transect (Saffer et al. 2008). A sensitivity test was also performed with respect to the plate convergence rate and initial state of $\% \mathrm{~S}$.

\section{Results}

The veins hosted in the matrix shales of the Mugi mélange are $<1$ - to $12-\mathrm{mm}$ thick, with most being $<1 \mathrm{~mm}$ (Figure $2 \mathrm{~b}$ ). Figure $2 \mathrm{c}$ shows the spatial variation in vein frequency (Matsumura et al. 2003) and cumulative thickness at 1-m intervals. Veins are concentrated within sedimentary horizons near the fault zone below the basalt (Matsumura et al. 2003), with this heterogeneity also apparent in the cumulative thickness distribution. In addition, vein density is lithology-dependent, with fewer veins in horizons containing abundant sandstone and siliceous shale lenses, and more frequent veining within homogeneous shales. In total, the mineralized veins occupy approximately 0.4 vol.\% of the total amount of rock (bulk rock) along the transect. This value of volume fraction is comparable to the previous estimation for veins related to shear fabrics in the Yokonami mélange, which is another exhumed tectonic mélange in the Shimanto Belt, Shikoku (approximately 1 vol.\%; Hashimoto et al. 2012).

Figure 3 shows the bulk-XRD pattern of ML-01, and relative mineral abundances calculated from the patterns are listed in Table 1. The two samples have almost the same mineral compositions, consisting of $50 \mathrm{wt} . \%$ of clays, 40 wt.\% of quartz, 15 wt.\% of plagioclase, and trace amounts of calcite.

Figure 4 shows the clay-fraction XRD pattern (ML-01) in AD (lower) and EG (upper) states. The pattern shows basal reflections from chlorite (14.42 and 7.12 $\AA$ ) and illite (approximately $10 \AA$ ), but the asymmetric profile of the 10-A band and its slight shift by EG solvation indicates the presence of an expandable S-I phase. Biscaye's factor yields approximately 3:7 for the weight ratio between chlorite and S-I (Table 1). The decomposition result suggests that the $10-\AA$ S-I band is explained by four overlapping peaks at 10.8, 10.4, 10.0, and $9.9 \AA$ 


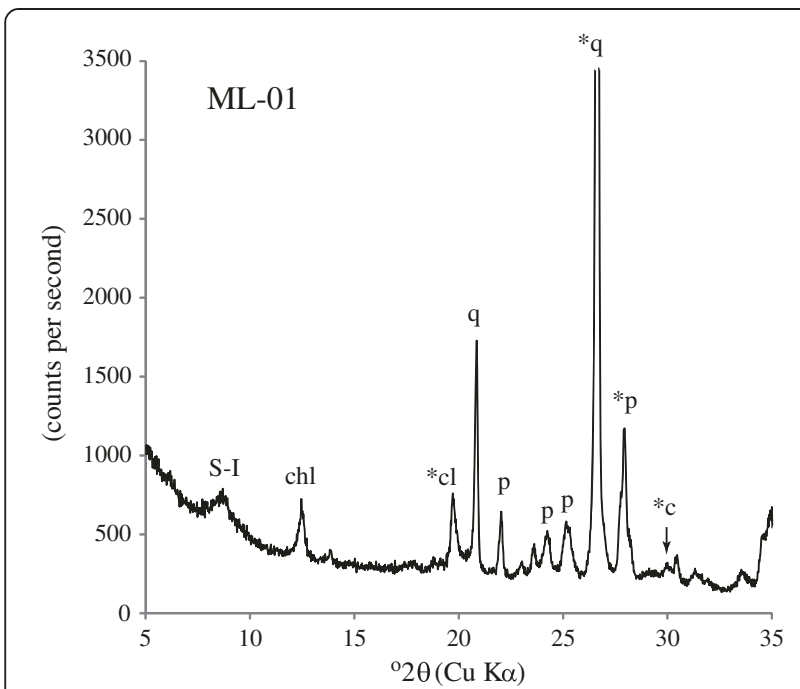

Figure 3 Bulk XRD pattern of ML-01 sample. chl, chlorite; Cl, clay composite; q, quartz; p, plagioclase; and c, calcite. Reflections with an asterisk were used for semi-quantitative analysis of bulk rock compositions.

(Figure 5; Table 2). The 10.4- and 10.0- $\AA$ peaks likely correspond to poorly crystallized and well-crystallized illite, respectively, that are commonly observed in late-stage diagenetic sedimentary basins (Lanson 1997; Lanson et al. 1998). However, it is uncertain whether the two peaks in our samples imply the occurrence of two distinct phases such as authigenic illite and detrital mica, or artificial interpretation of a single phase with a wide population of coherent scattering domain sizes (Lanson 1997). In addition to the peaks for discrete illite, the fitting procedure requires two more peaks at approximately 10.8 and approximately $9.9 \AA$ in order to keep consistency with the interpretation of the $\mathrm{AD}$ profile. Based on the NEWMOD calculation, these peaks are ascribed to those for ordered $(R=3)$ S-I of approximately $10 \% \mathrm{~S}$.

Figure 6a shows the results of calculations of S-I reactions in progress along the modeled transect (Nankai margin). The S-I reaction starts at around $70^{\circ} \mathrm{C}$ and continues up to temperatures of around $300^{\circ} \mathrm{C}$. The two geothermal models do not significantly affect the modeling results (Figure 6a).

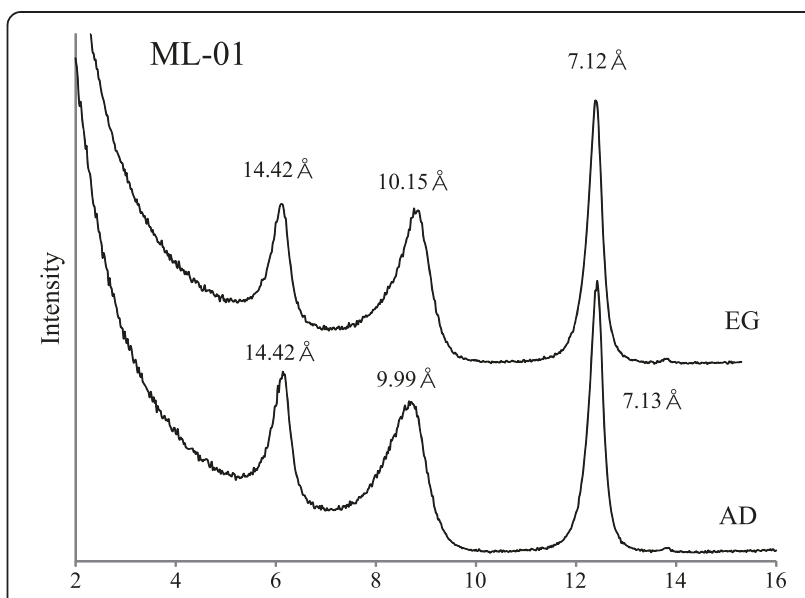

Figure 4 XRD patterns for oriented mounts of clay-fraction specimen (ML-01) in air-dried (AD) and ethylene-glycolated (EG) states.

\section{Discussions}

\section{Origin of $\mathrm{SiO}_{2}$ for mineralized veins}

The majority of $\mathrm{SiO}_{2}$ in the veins observed along the transect is thought to have originated from pressure solution of detrital quartz and feldspar in deformed shales (Kawabata et al. 2007). Kawabata et al. (2007) determined the variation in whole-rock geochemistry of scaly shales in the Mugi mélange, and used a Ti-normalized isocon approach (Grant 1986) to estimate a total volume loss of 17 to 54 vol.\% from the deformed mélanges during pressure solution deformation, the majority of which was fluid-mobile $\mathrm{SiO}_{2}$. However, this value represents a net volume reduction and should therefore also involve other sources, e.g., S-I or illite-muscovite reactions. In order to quantify the amount of $\mathrm{SiO}_{2}$ contributed to this volume loss by the various sources, we determined the amount of $\mathrm{SiO}_{2}$ removed by $\mathrm{S}$-I reactions as follows.

Using end-member chemical formulae of smectite and illite, and assuming $\mathrm{Al}_{2} \mathrm{O}_{3}$ to be constant during the reaction, van de Kamp (2008) derived one example of reaction equation for illitization reaction;

$$
\begin{aligned}
& 1.308\left[\begin{array}{l}
\left(\mathrm{Al}_{3.15} \mathrm{Mg}_{0.85}\right)\left(\mathrm{Si}_{8.00}\right) \mathrm{O}_{20}(\mathrm{OH})_{4}\left(\mathrm{Na}_{0.85}\right) 2 \mathrm{H}_{2} \mathrm{O}+ \\
\left(0.06 \mathrm{Fe}_{2} \mathrm{O}_{3}+0.56 \mathrm{~K}_{2} \mathrm{O}+0.02 \mathrm{CaO}\right)
\end{array}\right] \\
& \left(\begin{array}{l}
\left.\mathrm{Al}_{4.12} \mathrm{Fe}_{0.1} \mathrm{Mg}_{0.56}\right)\left(\mathrm{Si}_{7.17}\right) \mathrm{O}_{20}(\mathrm{OH})_{4}\left(\mathrm{~K}_{1.47} \mathrm{Na}_{0.01} \mathrm{Ca}_{0.03}\right)+ \\
3.29 \mathrm{SiO}_{2}+0.56 \mathrm{Na}_{2} \mathrm{O}+0.55 \mathrm{MgO}+3.23 \mathrm{H}_{2} \mathrm{O}
\end{array}\right]
\end{aligned}
$$

\begin{tabular}{|c|c|c|c|c|c|c|c|c|c|c|c|c|c|c|}
\hline \multirow[t]{2}{*}{ Sample } & \multicolumn{2}{|c|}{ Total clay } & \multicolumn{2}{|c|}{ Quartz } & \multicolumn{2}{|c|}{ Plagioclase } & \multicolumn{2}{|c|}{ Calcite } & \multicolumn{3}{|c|}{ S-I } & \multicolumn{3}{|c|}{ Chlorite } \\
\hline & Area & wt. $\%$ & Area & wt.\% & Area & wt.\% & Area & wt. $\%$ & Area & $\begin{array}{l}\text { wt.\% in clay } \\
\text { fraction* }\end{array}$ & $\begin{array}{l}\text { wt. } \% \text { in bulk } \\
\text { rock }^{* *}\end{array}$ & Area & $\begin{array}{l}\text { wt.\% in clay } \\
\text { fraction }\end{array}$ & $\begin{array}{l}\text { wt. } \% \text { in bulk } \\
\text { rock }\end{array}$ \\
\hline$\overline{M L}-01$ & 134 & 50 & 1,747 & 36 & 333 & 14 & 5 & Trace & 3,183 & 70 & 35 & 2,713 & 30 & 15 \\
\hline ML-02 & 121 & 45 & 2,007 & 39 & 381 & 16 & 22 & Trace & 2,829 & 74 & 33 & 1,970 & 26 & 12 \\
\hline
\end{tabular}

Table 1 Integrated peak intensities and calculated bulk rock mineral compositions

${ }^{*}$ wt. $\%$ of S-I in clay fraction sample estimated by Biscaye's weighting factor.

${ }^{* *}$ wt.\% of S-I in bulk sample (=wt.\% of total clay in bulk rock $\times$ wt.\% of S-I in clay fraction). 


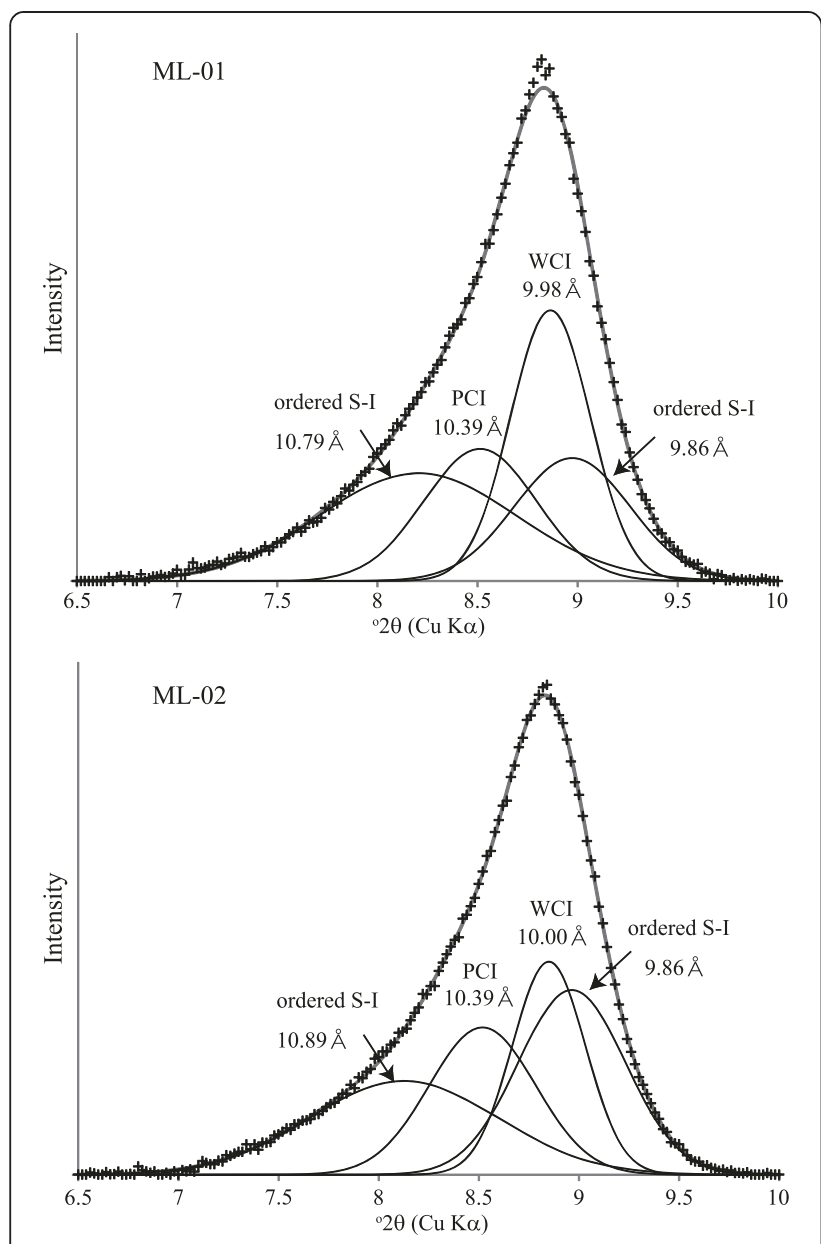

Figure 5 Decomposition of 10-Å band in EG state. Two peaks for ordered S-I were introduced to consistently interpret both $A D$ and EG profiles. PCl, poorly crystallized illite; WCl, well-crystallized illite.

This equation predicts that the S-I reaction yields 18 wt.\% $\mathrm{SiO}_{2}$ from primary smectite. Boles and Franks (1979), using a different chemical composition, estimated a $\mathrm{SiO}_{2}$ loss of 23.3 wt.\%, while Leder and Park (1986) suggested a loss as high as $28 \mathrm{wt} . \%$. Above $200^{\circ} \mathrm{C}$, the illite-muscovite conversion reaction will be enhanced and can liberate a further 17 to 23 wt.\% of $\mathrm{SiO}_{2}$ from the original illite (van de Kamp 2008). Therefore, if one assumes a shale containing $50 \mathrm{wt} . \%$ smectite, the S-I reaction can potentially yield 9 to 14 wt.\% of $\mathrm{SiO}_{2}$ from bulk sediments (18 to 28 wt.\% of primary smectite) until the completion of the reaction.

At subduction margins, extensive research has quantified the mineralogy of incoming sediments (Underwood 2007). At the Nankai margin, smectite comprises some 20 to 50 wt.\% of the bulk sediments within the Lower Shikoku Basin facies, which hosts the décollement-equivalent horizon, yielding a possible 4 to 14 wt. $\%$ of $\mathrm{SiO}_{2}$ mobilized by the $\mathrm{S}-\mathrm{I}$ reaction.

Our XRD analyses show that the two shale samples have almost identical mineral compositions, containing approximately $35 \mathrm{wt} \%$ of S-I, possibly as a product of a diagenetic reaction (Table 1 ). Considering previous reports on the relatively homogeneous nature of the matrix shale throughout the units (units I, II, and III; Ikesawa et al. 2005; Kawabata et al. 2007), the mineralogical properties shown here are thought to be representative of the whole units in this area. The weight fraction of $35 \mathrm{wt} . \%$ of S-I in the shale is almost equivalent to the smectite content in the Nankai sediments, and thus, comparable amounts of $\mathrm{SiO}_{2}$ (i.e., 4 to 14 wt.\%) may have been released from the shales of the Mugi mélange. However, if we consider the net volume of $\mathrm{SiO}_{2}$ removed at temperatures of $<200^{\circ} \mathrm{C}$, the isocon methods suggest a 35 wt.\% loss of $\mathrm{SiO}_{2}$ from the original mudstone (Kawabata et al. 2007). This indicates that up to $40 \%$ of the total mass loss estimated by the isocon method was explained by S-I reactions, with the rest attributable to pressure solution of detrital quartz and feldspar. Liberation of as much as $14 \mathrm{wt} . \% \mathrm{SiO}_{2}$ from the original mudstone is obviously enough to account for the observed quartz veining in the Mugi mélange, meaning that this excess $\mathrm{SiO}_{2}$ may have cemented associated sandstones, or may have left the system.

Moore and Allwardt (1980) suggested that incipient pressure solution occurs in exhumed accretionary complexes that undergo diagenesis at temperatures of $100^{\circ} \mathrm{C}$ to $120^{\circ} \mathrm{C}$, with this process being dominant at temperatures above $200^{\circ} \mathrm{C}$. Although the onset of pressure solution in the Mugi mélange has not been well constrained, pervasive pressure solution seams defined by dark cleavages are present in shales that were deformed at around $150^{\circ} \mathrm{C}$ (Kawabata et al. 2007). In contrast, the behavior of $\mathrm{SiO}_{2}$ mobilized during the $\mathrm{S}$-I reaction can be more quantitatively assessed by kinetic modeling. Here, we

Table 2 Results of peak decomposition for the I-S band

\begin{tabular}{|c|c|c|c|c|c|c|c|c|c|c|c|c|}
\hline \multirow[t]{2}{*}{ Sample } & \multicolumn{3}{|c|}{ Ordered S-I (low angle) } & \multicolumn{3}{|c|}{$\mathrm{PCl}$} & \multicolumn{3}{|c|}{ WCI } & \multicolumn{3}{|c|}{ Ordered S-I (high angle) } \\
\hline & $2 \theta$ & Intensity & FWHM & $2 \theta$ & Intensity & FWHM & $2 \theta$ & Intensity & FWHM & $2 \theta$ & Intensity & FWHM \\
\hline ML-01 & 8.20 & 440 & 1.15 & 8.51 & 540 & 0.66 & 8.86 & 1,107 & 0.469 & 8.96 & 502 & 0.68 \\
\hline ML-02 & 8.12 & 492 & 1.11 & 8.51 & 774 & 0.63 & 8.84 & 1,120 & 0.43 & 8.96 & 971 & 0.63 \\
\hline
\end{tabular}

$\mathrm{PCl}$ and $\mathrm{WCl}$ are poorly and well-crystallized illite, respectively (see text). 

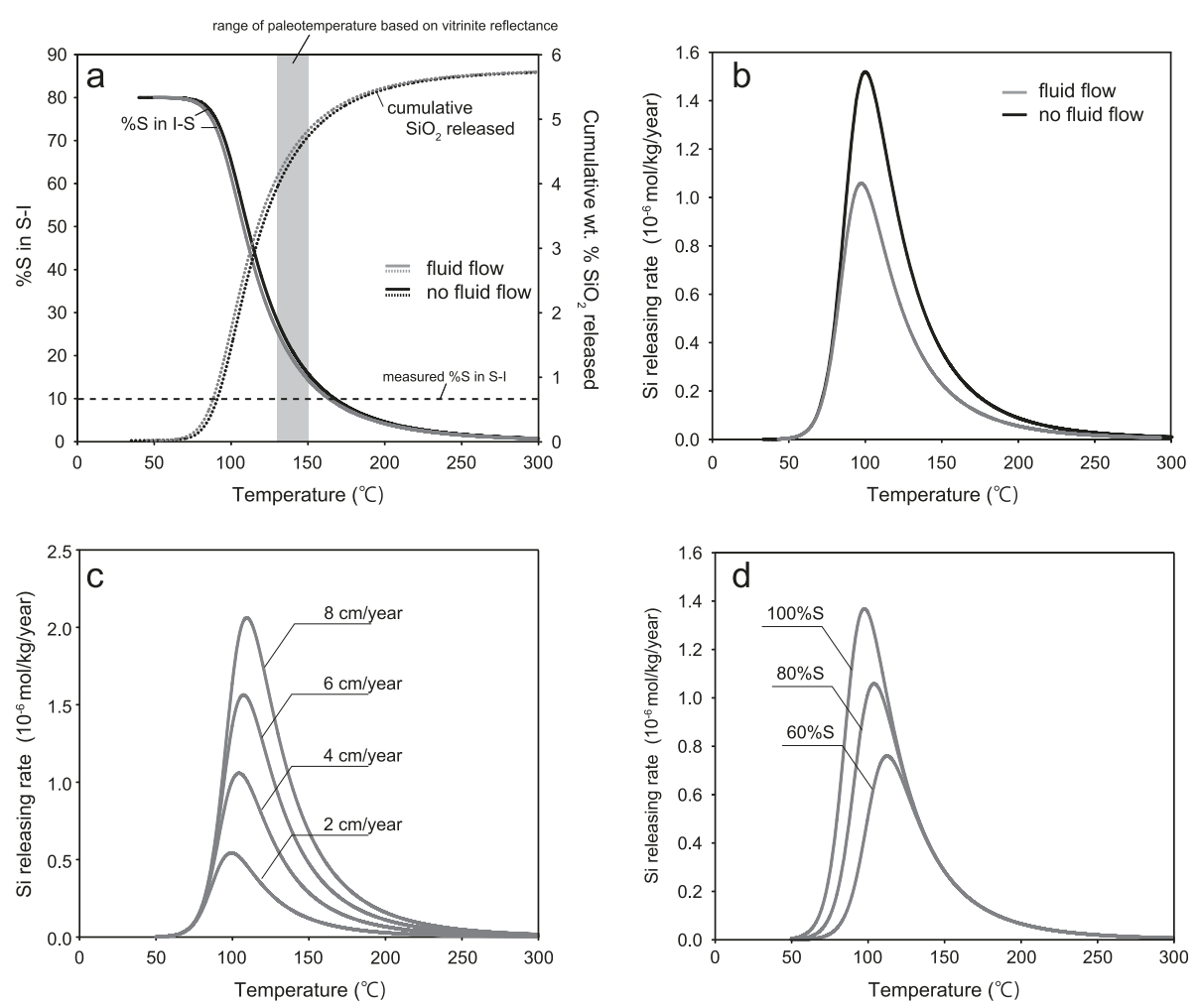

Figure 6 Curves for calculated S-I reaction progress, release rate of $\mathrm{SiO}_{2}$, and sensitivity test results. (a) Calculated S-I reaction progress at plate interface along modeled thermal structures of Muroto transect with and without fluid flow (Spinelli and Wang 2008), indicating cumulative amounts of $\mathrm{SiO}_{2}$ loss during the reaction. (b) Release rate of $\mathrm{SiO}_{2}$ as a function of temperature. Results of sensitivity test for (c) plate convergence rate and $(\mathbf{d})$ initial state of\%S in S-I.

reproduce S-I reaction pathways along the Nankai Trough plate interface as an analog setting for the Mugi mélange (Figure 6a). In these calculations, we assume that the initial content of smectite in the incoming deposit is 40 wt.\%, and that 18 wt.\% of $\mathrm{SiO}_{2}$ was liberated as a proportion of the original smectite until the end of the reaction. In addition to the results of calculations of the $\mathrm{S}$-I reaction progress, Figure $6 \mathrm{a}$ also shows cumulative $\mathrm{SiO}_{2}$ liberation during this reaction. As the reaction proceeds, approximately 6 wt. $\% \mathrm{SiO}_{2}$ is progressively released from the underthrusting deposit; Figure 6b shows the rate of $\mathrm{SiO}_{2}$ release as a function of temperature. This calculation demonstrates that the $\mathrm{S}-\mathrm{I}$ reaction actively supplies $\mathrm{SiO}_{2}$ at temperatures of $70^{\circ} \mathrm{C}$ to $200^{\circ} \mathrm{C}$, with the reaction continuing at higher temperatures. A sensitivity test indicates that the reaction temperature does not change significantly within the parameter ranges examined, while the reaction rate is highly dependent on variables such as the plate convergence rate and initial states of $\% \mathrm{~S}$ (Figure $6 \mathrm{c}, \mathrm{d}$ ). The temperature range for the active release of $\mathrm{SiO}_{2}$ is comparable to the estimated formation temperatures of quartz veins in the Mugi mélange $\left(125^{\circ} \mathrm{C}\right.$ to $\left.245^{\circ} \mathrm{C}\right)$.

\section{Comparison between kinetic prediction of S-I conversion and actual state of S-I in on-land samples}

To check the validity of the kinetically predicted reaction progress of S-I conversion, the modeling results were compared with the mixed-layer S-I in the Mugi mélange. As mentioned earlier, the peak decomposition of approximately $10-\AA$ reflection indicates that the S-I phase in the samples is ordered $(R=3)$ S-I of approximately $10 \% \mathrm{~S}$. It is noted that $10 \% \mathrm{~S}$ of $\mathrm{S}-\mathrm{I}$ is slightly lower than the kinetically expected value $(15 \% \mathrm{~S}$ to $25 \% \mathrm{~S}$; Figure $6 \mathrm{a})$, considering the maximum paleotemperature of the Mugi mélange from vitrinite reflectance measurements $\left(130^{\circ}\right.$ $\mathrm{C}$ to $150^{\circ} \mathrm{C}$; Ikesawa et al. 2005).

Although the downhole progress of S-I conversion at the Nankai margin was successfully reproduced by the above kinetic expressions (Saffer et al. 2008), it is uncertain as to whether they are still applicable to modeling of diagenesis at great depths. In fact, K-feldspar was rarely detected by XRD in the analyzed shales, possibly because of completion of the albitization reactions of feldspars (Moore et al. 2007), and it is therefore probable that the activity ratio of $\mathrm{K} / \mathrm{Na}$ in such conditions is controlled by other equilibrium states (e.g., albite-illite 
equilibrium). Moreover, deformation features such as mélange fabric and pervasive pressure solution cleavages are apparent in the analyzed samples. It has been inferred that the S-I reaction can be accelerated by deformation itself (e.g., Vrolijk and van der Pluijm 1999) and/or chemical anomaly of circulated fluids during deformation (e.g., Dellisanti et al. 2008). Although the sampling site of ML-01 is located in the vicinity of the basalt rock (at a distance of $5 \mathrm{~m}$ ), close similarity of the two XRD patterns suggests that the S-I reaction may not have been affected by basalt-related deformation and/or fluids. However, both samples are involved in tectonic processes of mélange formation, and if these processes foster the rate of the conversion reaction, active $\mathrm{SiO}_{2}$ liberation will take place at a slightly lower temperature condition than the theoretical estimation.

\section{Implications for seismogenesis at subduction zones}

The liberation and deposition of $\mathrm{SiO}_{2}$ observed in the Mugi mélange provides insights into the mechanical evolution of the subduction zone plate interface, and has two specific consequences for seismogenesis. First, quartz cementation and/or veining cause progressive lithification of the décollement zone and may enhance velocity-weakening behavior (Byrne 1998; Moore and Saffer 2001). Frictional experiments indicate that quartz can cause a velocity-weakening response (e.g., Blanpied et al. 1995; Ikari et al. 2011; Saito et al. 2013), in contrast to the majority of clay minerals, which have velocitystrengthening behaviors (e.g., Saffer and Marone 2003; Ikari et al. 2011). As the original mudstone is dominated by clays, successive quartz infilling, particularly in cracks along the shear fabrics, is thought to be an important process that can lead to unstable slip. It is also noted that the timing and P-T condition of quartz veining in the Mugi mélange may be comparable to the source region of VLFE in the Nankai accretionary prism (Figure 7; e.g., Sugioka et al. 2012). Recently, friction experiments by Saito et al. (2013) demonstrated that a quartz-rich material is favorable for the occurrence of VLFE. They also suggested that a tectonic mélange lithified by quartz veining and cementation can be a source rock for VLFE. Hence, these diagenetic processes are thought to be intimately correlated to subduction zone seismogenesis.

The second important aspect is an increase in the intrinsic frictional coefficient of the décollement, which may eventually lead to décollement step-down into the subducting oceanic basalt (Figure 7). Tectonic mélanges often include slabs or fragments of oceanic basalt, the presence of which can be explained by décollement step-down and subsequent underplating of the downgoing mélange, in addition to movement of the upper part of the basement into the overriding plate (Kimura and Ludden 1995; Kimura et al. 2011). Ikesawa et al. (2005) identified fault rocks such as cataclasites and ultracataclasites at the base of a section of incorporated basalt and argued that fracturing of basalt is a seismogenic process. The occurrence of high-velocity frictional slip on this fault has been also inferred from several lines of geological evidence, including a rapid injection of basalt-derived fluidized granular material during faulting (Ujiie et al. 2007), stretching of fluid inclusions in calcite by frictional heating (Ujiie et al. 2008), and progress of chloritization in fluidized rock due to frictional heating (Kameda et al. 2011). In addition, it is thought that sites of décollement step-down coincide with the upper aseismic-seismic transition (Matsumura et al. 2003), although the actual controls of this tectonic process are poorly understood. Progressive hardening by ongoing quartz veining and/or cementation is a possible process to increase the frictional strength of the sedimentary décollement by which fracturing can break through to relatively weak levels within the basalt (Figure 7). The initiation of active quartz deposition at temperatures of

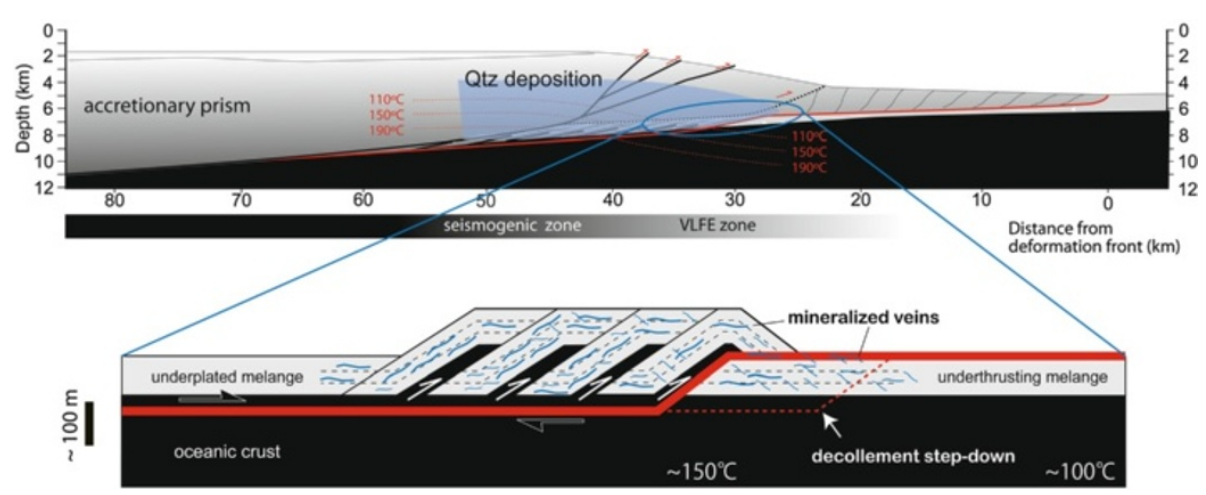

Figure 7 Schematic model of a subduction zone. Model indicates areas of quartz deposition and onset of décollement step-down into areas of oceanic basalt. VLFE (very-low-frequency earthquake) zone is from Obana and Kodaira (2009) and Sugioka et al. (2012). Mineralized veining may cause hardening of the underthrusting mélange, leading to the onset of seismogenesis such as VLFE and fracturing of the oceanic basalt (see text for details). 
$100^{\circ} \mathrm{C}$ is consistent with the onset of décollement stepdown at around $150^{\circ} \mathrm{C}$.

\section{Conclusion}

This work examined the liberation and deposition processes of $\mathrm{SiO}_{2}$ in the deformed shale (the Mugi mélange in the Shimanto accretionary complex), which represents typical deformation features at subduction zone plate boundaries. XRD analysis of the rock and kinetic modeling suggest that the underthrusting of incoming sediments may rapidly foster S-I reactions to release $\mathrm{SiO}_{2}$ at temperatures from approximately $100^{\circ} \mathrm{C}$. This condition is consistent with the formation temperatures of quartz veins inferred from fluid inclusion microthermometry. Moreover, the potential mass of $\mathrm{SiO}_{2}$ released during the reaction is large enough to account for the total volume of the veins in the analyzed transect. Progressive $\mathrm{SiO}_{2}$ deposition may be linked to plate boundary seismogenesis, including VLFE and décollement step-down into the oceanic basement during underplating.

\section{Competing interests}

The authors declare that they have no competing interests.

\section{Authors' contributions}

JK carried out the mineralogical analysis and drafted the manuscript. KK, YH, $A Y$, and GK participated in the field survey. All authors read and approved the final manuscript.

\section{Acknowledgements}

We thank H. Tobin, K. Ujiie, and H. Ueda for many suggestions that improved this paper. We also thank J. Ashi and two anonymous reviewers for their careful reviews. DECOMPXR was kindly provided by B. Lanson. This work was supported by Grants-in-Aid for young scientists (24740339) from JSPS, the 'Nanotechnology Platform' project (12024046), and Grants-in-Aid for Scientific Research on Innovative Areas (21107005) from MEXT.

\section{Author details}

${ }^{1}$ Earth and Planetary System Science, Department of Natural History Sciences, Graduate School of Science, Hokkaido University, N10 W8, Sapporo 060-0810, Japan. ${ }^{2}$ Institute for Research on Earth Evolution, Japan Agency for Marine Earth Science and Technology, Yokosuka, Japan. ${ }^{3}$ Department of Earth and Planetary Science, Graduate School of Science, The University of Tokyo, Tokyo, Japan. ${ }^{4}$ Atmosphere and Ocean Research Institute, The University of Tokyo, Chiba, Japan.

\section{Received: 30 October 2013 Accepted: 24 March 2014}

Published: 16 April 2014

\section{References}

Ando M, Tu Y, Kumagai H, Yamanaka T, Lin CH (2012) Very low frequency earthquakes along the Ryukyu subduction zone. Geophys Res Lett 39, L04303. Doi: 10.1029/2011GL050559

Biscaye PE (1965) Mineralogy and sedimentation of recent deep-sea clays in the Atlantic Ocean and adjacent seas and oceans. Geol Soc Am Bull 76:803-832

Blanpied ML, Lockner DA, Byerlee JD (1995) Frictional slip of granite at hydrothermal conditions. J Geophys Res 100(13):13045-13064

Boles JR, Franks SG (1979) Clay diagenesis in Wilcox sandstones of southwest Texas: implications of smectite diagenesis on sandstone cementation. J Sediment Petrol 49:55-70

Byrne T (1998) Seismicity, slate belts and coupling along convergent plate boundaries. EOS Trans AGU 79:W-114

Dellisanti F, Pini GA, Tateo F, Baudin F (2008) The role of tectonic shear strain on the illitization mechanism of mixed-layers illite-smectite. A case study from a fault zone in the Northern Apennines, Italy. Int J Earth Sci (Geol Rundsch) 97:601-616. doi: 10.1007/s00531-007-0180-4

Grant JA (1986) The isocon diagram-a simple solution to Gresens' equation for metasomatic alteration. Econ Geol 81:1976-1982

Hashimoto Y, Eida M, Kirikawa T, lida R, Takagi M, Furuya N, Nikaizo A, Kikuchi T, Yoshimitsu T (2012) Large amount of fluid migration around shallow seismogenic depth preserved in tectonic mélange: Yokonami mélange, the Cretaceous Shimanto Belt, Kochi, Southwest Japan. Isl Arc 21:53-64

Hower J, Eslinger E, Hower ME, Perry EA (1976) Mechanism of burial metamorphism of argillaceous sediment: 1. Mineralogical and chemical evidence. Geol Soc Am Bull 87:725-737

Hyndman RD (2007) The seismogenic zone of subduction thrust faults. In: Dixon T, Moore JC (ed) The seismogenic zone of subduction thrust faults. Columbia University Press, New York

Ikari MJ, Marone C, Saffer DM (2011) On the relation between fault strength and frictional stability. Geology 39:83-86. Doi: 10.1130/G31416.1

Ikesawa E, Kimura G, Sato K, Ikehara-Ohmori K, Kitamura Y, Yamaguchi A, Ujiie K, Hashimoto Y (2005) Tectonic incorporation of the upper part of oceanic crust to overriding plate of a convergent margin: an example from the Cretaceous-early Tertiary mélange, the Shimanto Belt, Japan. Tectonophys 401:217-230. Doi: 10.1016/j.tecto.2005.01.005

Ito $Y$, Obara K (2006) Dynamic deformation of the accretionary prism excites very low frequency earthquakes. Geophys Res Lett 33:L02311. Doi: 10.1029/ 2005GLO25270

Kameda J, Ujiie K, Yamaguchi A, Kimura G (2011) Smectite to chlorite conversion by frictional heating along a subduction thrust. Earth Planet Sci Lett 305:161-170. Doi: 10.1016/j.epsl.2011.02.051

Karig D, Morgan J (1994) Tectonic deformation: stress paths and strain histories. In: Maltman A (ed) The geological deformation of sediments. Chapman \& Hall, New York, pp 167-204

Kawabata K, Tanaka H, Kimura G (2007) Mass transfer and pressure solution in deformed shale of accretionary complex: examples from the Shimanto Belt, southwest Japan. J Struct Geol 29:697-711. Doi: 10.1016/j.jsg.2006.11.009

Kimura G, Ludden J (1995) Peeling oceanic crust in subduction zone. Geology 23:217-220

Kimura G, Yamaguchi A, Hojo M, Kitamura Y, Kameda J, Ujiie K, Hamada Y, Hamahashi M, Hina S (2011) Tectonic mélange as fault rock of subduction plate boundary. Tectonophys 568-569:25-38

Kitamura Y, Sato K, Ikesawa E, Ikehara-Ohmori K, Kimura G, Kondo H, Ujiie K, Onishi CT, Kawabata K, Hashimoto Y, Mukoyoshi H, Masago H (2005) Mélange and its seismogenic roof décollement: a plate boundary fault rock in the subduction zone-an example from the Shimanto Belt, Japan. Tectonics 24, TC5012. Doi: 10.1029/2004TC001635

Lanson B (1997) Decomposition of experimental X-ray diffraction patterns (profile fitting): a convenient way to study clay minerals. Clays Clay Miner 45:132-146

Lanson B, Velde B, Meunier A (1998) Late state diagenesis of illitic clay minerals as seen by decomposition of $\mathrm{X}$-ray diffraction patterns: contrasted behaviors of sedimentary basins with different histories. Clays Clay Miner 46:69-78

Laubach SE, Olson JE, Gale JFW (2004) Are open fractures necessarily aligned with maximum horizontal stress? Earth Planet Sci Lett 222:191-195

Leder F, Park WC (1986) Porosity reduction in sandstone by quartz overgrowth. Am Ass Petrol Geol Bull 70:1713-1728

Lockner D, Byerlee J (1986) Laboratory measurements of velocity-dependent frictional strength. U.S. Geological Survey Open-File Report, Menlo Park 86-417. 26-417

Matsumura M, Hashimoto Y, Kimura G, Ohmori-lkehara K, Enjohji M, Ikesawa E (2003) Depth of oceanic-crust underplating in a subduction zone: inferences from fluid-inclusion analyses of crack-seal vein. Geology 31:1005-1008. Doi: 10.1130/ G19885.1

McBride EF (1989) Quartz cement in sandstones: a review. Earth Sci Rev 26:69-112

Moore JC, Allwardt A (1980) Progressive deformation of a Tertiary trench slope, Kodiak Islands, Alaska. J Geophys Res 85:4741-4756

Moore JC, Saffer D (2001) Updip limit of the seismogenic zone beneath the accretionary prism of southwest Japan: an effect of diagenetic to low-grade metamorphic processes and increasing effective stress. Geology 29:183-186

Moore JC, Rowe C, Meneghini F (2007) How accretionary prisms elucidate seismogenesis in subduction zones. In: Dixon T, Moore JC (ed) The seismogenic zone of subduction thrust faults. Columbia University Press, New York

Obana K, Kodaira S (2009) Low-frequency tremors associated with reverse faults in a shallow accretionary prism. Earth Planet Sci Lett 287:168-174. Doi: 10.1016/j.epsl.2009.08.005 
Onishi CT, Kimura G (1995) Change in fabric of mélange in the Shimanto Belt, Japan: change in relative convergence? Tectonics 14:1273-1289

Pytte AM, Reynolds RC (1989) The thermal transformation of smectite to illite. In: Naeser ND, McCulloh TH (ed) The thermal history of sedimentary basins. Springer, New York, pp 133-140

Reynolds RC, Jr (1985) NEWMOD a computer program for the calculation of one-dimensional diffraction patterns for mixed-layered clays. R.C. Reynolds, 8 Brook Rd., Hanover, New Hampshire 03755, USA

Saffer D, Marone C (2003) Comparisons of smectite- and illite-rich gouge, frictional properties: applications to the updip limit of the seismogenic zone of subduction thrusts. Earth Planet Sci Lett 215:219-235

Saffer DM, Mckiernan AW (2009) Evaluation of in situ smectite dehydration as a pore water freshening mechanism in the Nankai Trough, offshore southwest Japan. Geochem Geophys Geosys 10, Q02010. Doi: 10.1029/2008GC002226

Saffer DM, Underwood MB, McKiernan AW (2008) Evaluation of factors controlling smectite transformation and fluid production in subduction zones: application to the Nankai Trough. Isl Arc 17:208-230. Doi: 10.1111/ j.1440-1738.2008.00614.x

Saito T, Ujiie K, Tsutsumi A, Kameda J, Shibazaki B (2013) Geological and frictional aspects of very-low-frequency earthquakes in an accretionary prism. Geophys Res Lett 40:703-708. Doi: 10.1002/grl.50175

Shibata T, Orihashi Y, Kimura G, Hashimoto Y (2008) Deformation style of slickenlines on mélange foliations and change in deformation mechanisms along subduction interface: example from the Cretaceous Shimanto Belt, Shikoku, Japan. Isl Arc 17:376-393. Doi: 10.1111/j.1440-1738

Spinelli GA, Wang K (2008) Effects of fluid circulation in subducting crust on Nankai margin seismogenic zone temperatures. Geology 36:887-890. Doi: 10.1130/G25145A

Steurer JF, Underwood MB (2003) Clay mineralogy of mudstones from the Nankai Trough reference sites 1173 and 1177 and frontal accretionary prism site 1174. In: Mikida H, Moore GF, Taira A, Becker K, Moore JC, Klaus A (ed) Proc. ODP, Sci. Results, 190/196. Ocean Drilling Program, College Station

Sugioka H, Okamoto T, Nakamura T, Ishihara Y, Ito A, Obana K, Kinoshita M, Nakahigashi K, Shinohara M, Fukao Y (2012) Tsunamigenic potential of the shallow subduction plate boundary inferred from slow seismic slip. Nature Geosci 5:414-418

Taira A, Tashiro M, Okamura M, Katto J (1980) The geology of the Shimanto Belt in Kochi Prefecture, Shikoku, Japan. In: Taira A, Tashiro M (ed) Geology and paleontology of the Shimanto Belt. Rinyakosaikai Press, Kochi, pp 319-389

Ujiie K, Yamaguchi A, Kimura G, Toh S (2007) Fluidization of granular material in a subduction thrust at seismogenic depths. Earth Planet Sci Lett 259:307-318

Ujiie K, Yamaguchi A, Taguchi S (2008) Stretching of fluid inclusions in calcite as an indicator of frictional heating on faults. Geology 36:111-114. Doi: 10.1130/ G24263A.1

Underwood MB (2007) Sediment inputs to subduction zones: why lithostratigraphy and clay mineralogy matter. In: Dixon T, Moore JC (ed) The seismogenic zone of subduction thrust faults. Columbia University Press, New York

Underwood MB, Basu N, Steurer J, Udas S (2003) Data report: normalization factors for semiquantitative $X$-ray diffraction analysis, with application to DSDP site 297, Shikoku Basin. In: Mikida H, Moore GF, Taira A, Becker K, Moore JC, Klaus A (ed) Proc. ODP, Sci. Results, 190/196. Ocean Drilling Program, College Station, pp 1-28

van de Kamp PC (2008) Smectite-illite-muscovite transformations, quartz dissolution, and silica release in shales. Clays Clay Miner 56:66-81

Vrolijk P, van der Pluijm BA (1999) Clay gouge. J Struct Geol 21:1039-1048 Yamaguchi A, Ujiie K, Nakai S, Kimura G (2012) Sources and physicochemical characteristics of fluids along a subduction-zone megathrust: a geochemical approach using syn-tectonic mineral veins in the Mugi mélange, Shimanto accretionary complex. Geochem Geophys Geosys 13:Q0AD24. doi: 10.1029/ 2012 GC004137

doi:10.1186/1880-5981-66-13

Cite this article as: Kameda et al:: Quartz deposition and its influence on the deformation process of megathrusts in subduction zones. Earth, Planets and Space 2014 66:13.

\section{Submit your manuscript to a SpringerOpen ${ }^{\odot}$ journal and benefit from:}

- Convenient online submission

- Rigorous peer review

- Immediate publication on acceptance

- Open access: articles freely available online

- High visibility within the field

- Retaining the copyright to your article

Submit your next manuscript at $\gg$ springeropen.com 